\title{
SYSTEMATIC LITERATURE REVIEW IMPLEMENTASI HIGHER ORDER THINKING SKILLS (HOTS) TERHADAP HASIL BELAJAR SISWA
}

\author{
Dea Ananda*, Muhyani, dan Tjetjep Suhandi \\ Progam Studi Pendidikan Guru Madrasah Ibtidaiyah, \\ Universitas Ibn Khaldun Bogor, Indonesia \\ *Email: dea123186@gmail.com
}

\author{
Website: \\ https://jurnal.uinantasari.ac.id/index.php/adzka
}

Received: 11 Oktober 2020; Accepted: 11 Desember 2020; Published: 29 Desember 2020

DOI: $10.18952 /$ aladzkapgmi.v10i2.4005

\begin{abstract}
This research aims to: 1) describe the application of HOTS in the learning process at the elementary/mi level to students' learning outcomes; and 2) describe supporting and inhibiting factors in implementing HOTS. This research uses the Systematic Literature Review method or literature studies that focus on the process of examining and analyzing widely and thoroughly against some literature relevant to the topic of research. The literature used as the main source in this study is as much as 10 literature obtained from several data-based such as Garuda Portal, Google Scholar, and DOAJ published over the last 5 years (2016-2020). The results of this study show: 1) the application of HOTS in the learning process that takes place at the SD/MI level is effective to the student's learning outcomes compared to conventional learning; and 2) the success and inecapaness of the specified goals or criteria regardless of supporting factors or inhibition in implementing HOTS. Supporting factors are defined as important components that are considered to be able to support the successful implementation of HOTS which includes teacher competency, infrastructure facilities, classroom management, and learning planning. While the inhibitory factor is the constraints and difficulties faced in maximizing the application of HOTS which includes inadequate teacher education qualifications and a relatively low level of teacher understanding of HOTS implementation.
\end{abstract}

Keywords: Higher Order Thinking Skills (HOTS); learning outcomes; literature review

\begin{abstract}
ABSTRAK
Penelitian ini bertujuan untuk: 1) mendeskripsikan tentang penerapan HOTS dalam proses pembelajaran ditingkat SD/MI terhadap hasil belajar siswa; dan 2) menjabarkan faktor-faktor pendukung maupun penghambat dalam menerapkan HOTS. Penelitian ini menggunakan metode Systematic Literature Review atau kajian literatur yang menitikberatkan pada proses mengkaji dan menganalisis secara luas dan menyeluruh terhadap beberapa literatur yang relevan dengan topik penelitian. Data literatur yang digunakan sebagai sumber utama dalam penelitian ini sebanyak 10 literatur yang diperoleh dari beberapa data based seperti Portal Garuda, Google Scholar, dan DOAJ yang dipublikasikan dengan kisaran waktu 5 tahun terakhir (2016-2020). Hasil penelitian ini menunjukkan: 1) penerapan HOTS dalam proses pembelajaran yang berlangsung ditingkat SD/MI efektif terhadap hasil belajar siswa dibandingkan dengan pembelajaran komvensional; dan 2) keberhasilan dan ketidaktercapaian tujuan atau kriteria yang ditentukan tidak terlepas dari faktor-faktor pendukung maupun penghambat dalam menerapkan HOTS. Faktor pendukung diartikan sebagai komponen penting yang dinilai mampu menunjang keberhasilan penerapan HOTS yang meliputi kompetensi guru, sarana prasarana, manajemen kelas, dan perencanaan pembelajaran. Sementara faktor penghambat adalah kendala maupun kesulitan yang dihadapi dalam
\end{abstract}


memaksimalkan penerapan HOTS yang meliputi kualifikasi pendidikan guru yang kurang memadai dan tingkat pemahaman guru yang relatif rendah terhadap penerapan HOTS.

Kata Kunci: keterampilan berpikir tingkat tinggi; hasil belajar; kajian literatur.

\section{PENDAHULUAN}

Pendidikan merupakan sebuah pondasi utama yang harus dibangun dan diupayakan agar terus berkembang guna memperoleh hasil yang optimal sebagai landasan untuk menjalani kehidupan yang lebih baik. Sebagaimana yang tertuang dalam UU No. 20 Tahun 2003 Pasal 3 Tentang Sistem Pendidikan Nasional dikatakan bahwa tujuan pendidikan nasional adalah mengembangkan potensi peserta didik agar menjadi manusia yang beriman dan bertakwa kepada Tuhan Yang Maha Esa, berakhlak mulia, sehat, berilmu, cakap, kreatif, mandiri, dan menjadi warga negara yang demokratis serta bertanggung jawab. Untuk mencapai tujuan pendidikan tersebut maka konsep pendidikan yang menekankan pada upaya pemenuhan ilmu pengetahuan, keterampilan, dan pengalaman harus direalisasikan dalam bentuk proses pembelajaran yang dilaksanakan sehari-hari. Menurut (Zulyadaini, 2016:154) (dalam Isjoni, 2011:11) pembelajaran merupakan sebuah langkah yang dilakukan oleh tenaga pendidik untuk turut serta membantu, mengarahkan, dan mengupayakan peserta didik dalam memperoleh pengetahuan, keterampilan, dan pengalaman secara optimal selama proses pembelajaran yang berlangsung.

Hasil belajar dikatakan ideal apabila memenuhi dan mencapai seluruh aspek psikologis yang meliputi tiga aspek utama, yaitu kognitif, afektif, dan psikomotorik (Putri, 2013:225). Jika ditelaah secara seksama, kriteria hasil belajar yang ideal berkesinambungan dengan Kurikulum 2013 (K13) yang dirancang oleh pemerintah dengan tujuan untuk mengarahkan serta membentuk peserta didik agar menjadi sumber daya manusia (SDM) yang memiliki keterampilan, berkontribusi positif terhadap masyarakat serta berkompeten pada bidang tertentu. Berbekal hal tersebut diharapkan peserta didik memiliki potensi maupun keterampilan dibidang tertentu yang terus dikembangkan secara optimal sehingga menghasilkan kualitas dan mutu sumber daya manusia (SDM) yang berkompeten dan dapat bersaing dalam skala nasional maupun internasional di era globalisasi seperti saat ini. Seiring berkembangnya zaman dan tuntutan di era globalisasi, peserta didik dituntut untuk memiliki keterampilan abad 21 dimana keterampilan ini mengacu pada keterampilan seseorang untuk mampu berpikir tingkat tinggi atau yang dikenal dengan istilah Higher Order Thinking Skills (HOTS). Konsep HOTS berasal dari teori Taksonomi Bloom (1956) pada ranah kognitif yang mengacu pada proses perkembangan keterampilan secara intelektual dan mengubah cara berpikir seseorang secara kritis dan juga kreatif dari konkrit menuju abstrak (Rapih, 2018:77).

Dalam ranah pendidikan dasar dan menengah Higher Order Thinking Skills (HOTS) dikatakan sebagai komponen yang efektif pada ruang lingkup keterampilan untuk menghasillkan lulusan yang berkompeten sebagaimana yang tertuang dalam Lampiran Permendikbud No. 54 Tahun 2013 tentang Standar Kompetensi Lulusan tingkat SD/MI yakni memiliki kemampuan pikir dan tindak yang produktif dan kreatif dalam ranah abstrak dan konkret sesuai dengan yang ditugaskan kepadanya. (Arifin, 2017:95) (dalam Conklin, 2012:17) menilai jika Higher Order Thinking Skills (HOTS) memberikan nilai positif pada siswa dalam membentuk generasi yang berkualitas dan berkompeten pada bidang tertentu, melahirkan sosok yang bermanfaat, penuh inspirasi, berkepribadian unggul serta memiliki kontribusi positif di lingkungan masyarakat. Pembelajaran yang menekankan Higher Order Thinking Skills (HOTS) mengarah pada pengembangan keterampilan siswa dalam kegiatan analisis, evaluasi, dan mencipta melalui pendekatan saintifik yang dikemas dalam bentuk pembelajaran tematik integratif. Sudah semestinya HOTS mulai diterapkan sejak dini dan dikembangkan dengan tepat sehingga menghasilkan peserta didik yang aktif, mampu berpikir kritis dan kreatif serta menciptakan kualitas pembelajaran yang progresif dan efektif terhadap 
prestasi maupun pencapaian hasil belajar peserta didik. Hal ini harus diupayakan secara maksimal mengingat hasil survei Programme for International Student Assessment (PISA) pada tahun 2018 menunjukkan jika Indonesia menempati urutan ke 74 dari 79 negara atau dikatakan sebagai urutan keenam dari bawah (sumber: m.kumparan.com).

Jika melihat pada realitas yang terjadi, umumnya proses pembelajaran yang dilaksanakan pada institusi pendidikan tingkat SD/MI masih menerapkan pembelajaran secara konvensional. Pembelajaran konvensional dikenal sebagai metode tradisional yang dalam penerapannya didominasi oleh kegiatan ceramah yang diiringi oleh penjelasan materi dan cenderung berpusat pada guru (teacher centered) serta tidak melibatkan siswa secara utuh sebagai partisipan dalam proses pembelajaran. Hal ini menegaskan jika dalam penerapannya pembelajaran konvensional dinilai kurang optimal terhadap keseluruhan kondisi, keadaan, kebutuhan serta kesulitan maupun hambatan yang dialami oleh siswa (Fatmawati, 2017:135) (dalam Majid, 2014:165). Pembelajaran konvensional hanya menekankan pada hasil akhir yang dicapai oleh siswa dibandingkan proses yang harus dilalui siswa dalam mencapai tujuan tersebut. Demikian situasi ini tidak memberikan optimalisasi terhadap kematangan cara berpikir serta perkembangan potensi maupun keterampilan yang dimiliki oleh siswa hingga berpengaruh terhadap kesiapan siswa dalam menerima materi selanjutnya. Penyajian materi yang terkesan rumit dan padat yang tidak dikemas dalam bentuk sederhana hanya akan membuat materi yang telah disampaikan mudah terlupakan oleh siswa. Pembelajaran konvensional dalam proses pembelajaran dapat berjalan secara efisien namun hasil yang diperoleh cenderung belum memuaskan.

Sistem pembelajaran yang ideal harus mengacu pada proses keseimbangan antara peran guru dan siswa yang saling melengkapi. Kegiatan belajar mengajar (KBM) upayanya harus memaksimalkan kinerja otak dalam proses berpikir, sehingga kemampuan berpikir siswa dapat terus berkembang secara optimal dan mencapai pada keterampilan berpikir tingkat tinggi. Dikatakan bahwa semakin berkualitas dan meningkatnya kemampuan berpikir seseorang, maka hal ini akan berdampak positif pula terhadap hasil belajar yang diperoleh secara progresif (Yani, 2016:2). Dengan demikian penerapan HOTS dalam proses pembelajaran menitikberatkan pada keseimbangan antara proses dan hasil yang diperoleh siswa, bukan hanya sekadar membekali siswa dengan kemampuan berpikir pada level tinggi yang meliputi berpikir kritis, kreatif, dan evaluatif namun juga memberikan makna serta pengalaman tersendiri bagi siswa setelah mengikuti proses pembelajaran tersebut. Menurut (Karsono, 2017:51) proses pembelajaran yang efektif harus mampu menciptakan pembelajaran yang aktif, interaktif, berjalan secara kondusif, berpusat pada peserta didik (student centered), dan mengarah pada kemampuan berpikir tingkat tinggi.

Konsep Higher Order Thinking Skills (HOTS) dinilai mampu memberikan rangsangan positif terhadap perkembangan kognitif, memaksimalkan kemampuan siswa untuk menstransformasikan pengetahuan yang diperoleh dalam bentuk penyelesaian masalah yang tersaji di kehidupan sehari-hari, dan menghasilkan konsep-konsep baru yang aplikatif serta kaya akan informasi. Dengan demikian siswa akan mulai membiasakan diri untuk berpikir tingkat tinggi dalam proses pembelajaran sehari-hari sehingga memungkinkan siswa untuk memahami suatu topik atau materi tertentu secara menyeluruh. Ketika siswa memahami dan menguasai materi tertentu, maka hal tersebut akan mengacu pada kesiapan siswa untuk menerima materi ataupun pengetahuan selanjutnya. Dapat dikatakan jika hal ini akan memberikan nilai positif terhadap keberlangsungan proses belajar dan pencapaian prestasi maupun hasil belajar yang diperoleh siswa..

Berdasarkan uraian diatas, maka penerapan HOTS sejatinya penting untuk dikaji dan ditelaah secara luas dan menyeluruh mengingat impact yang dihasilkan cukup berpengaruh terhadap perkembangan kognitif siswa yang mengarah pada kemampuan berpikir secara 
kritis, kreatif, dan evaluatif sebagai dasar untuk menghadapi tantangan dan problematika di era globalisasi seperti saat ini. Terlebih penerapan HOTS ditingkat dasar belum begitu banyak direalisasikan dalam proses pembelajaran yang dilaksanakan sehari-hari mengingat masih minimnya akses koordinasi pihak sekolah dengan instansi terkait yang menyebabkan rendahnya tingkat pemahaman dan penguasaan guru mengenai HOTS dan cara mengaplikasikannya secara tepat. Penerapan HOTS tentunya tidak terlepas dari faktor pendukung maupun penghambat yang dihadapi ketika sedang atau telah melaksanakan pembelajaran tersebut. Sebelum memulai penerapan HOTS hendaknya para guru dapat memperhatikan dan memahami faktor pendukung maupun penghambat agar hal tersebut dapat dijadikan sebagai indikator dan acuan untuk memaksimalkan pelaksanaan pembelajaran agar berjalan secara kondusif, efektif, efisien serta mengarah pada peningkatan mutu dan kualitas pembelajaran yang progresif sekaligus turut andil dalam mengembangkan kemampuan berpikir siswa secara optimal. Dengan mengacu pada faktor-faktor tersebut upayanya guru dapat menekan angka kegagalan atau ketidaktercapaian proses pembelajaran yang menerapkan HOTS terhadap kriteria maupun tujuan pembelajaran yang telah ditentukan.

\section{METODE PENELITIAN}

Penelitian ini menggunakan metode systematic literature review. Systematic literature review merupakan salah satu bentuk penelitian yang menekankan pada proses dan kegiatan identifikasi, analisis, evaluasi, dan membuat kesimpulan terhadap keseluruhan hasil penelitian yang relevan dengan topik penelitian sehingga dapat digunakan sebagai landasan untuk memecahkan masalah yang ditetapkan (Triandini, 2019:64). Data yang digunakan dalam penelitian ini ialah data sekunder. Data sekunder adalah data yang diperoleh dari penelitian terdahulu dan tidak mengharuskan untuk melakukan pengamatan secara langsung (Muhyani, 2019:96). Sumber utama penelitian ini adalah 10 literatur yang diperoleh dari electronic based yang terindeks sinta, seperti Google Scholar, Direct of Open Access Journals (DOAJ), dan Portal Garuda yang telah melalui beberapa tahap penyaringan dan memenuhi kriteria. Langkah-langkah yang harus dilakukan dalam penelitian systematic literature review meliputi:

1. Perencanaan (planning) pada tahapan ini peneliti diharuskan untuk merumuskan langkahlangkah yang akan dilakukan dan menentukan research question;

2. Peninjauan (review), dimana kegiatan ini merupakan tahap pelaksanaan yang menitikberatkan pada proses pencarian literatur dari electronic based, kemudian peneliti memilih dan mengkategorikan literatur, melakukan screening dan menentukan literatur yang relevan serta membuat kesimpulan terhadap keseluruhan literatur yang ditetapkan;

3. Dokumentasi dilakukan dengan cara menuliskan dan menjabarkan hasil temuan dari literatur yang terpilih secara kompleks. Hasil temuan tersebut dijadikan landasan dalam menjawab research question yang ditentukan.

Untuk mendapatkan hasil yang efektif dan efisien, maka dalam melaksanakaan systematic literature review harus memperhatikan tahapan-tahapan berikut:

\section{A. Menentukan research question}

Pada tahap ini peneliti akan merumuskan dan menentukan pertanyaan yang sesuai dengan topik penelitian. Rumusan masalah yang ditentukan mengacu pada latar belakang masalah yang telah dipaparkan oleh peneliti. Berikut ini merupakan research question pada penelitian ini, yaitu:

1. $\mathrm{RQ}_{1}$ : Bagaimana penerapan HOTS ditingkat SD/MI terhadap hasil belajar siswa?

2. $\mathrm{RQ}_{2}$ : Apa sajakah faktor pendukung dan penghambat dalam menerapkan HOTS ditingkat $\mathrm{SD} / \mathrm{MI}$ ? 


\section{B. Proses Pencarian (Search Process)}

Proses pencarian (Search process) merupakan tahap pencarian dan menjelajahi literatur dari dari beberapa elektronic based yang terindeks sinta, seperti Google Scholar, Direct of Open Access Journals (DOAJ), dan Portal Garuda. Peneliti menilai ketiga data based tersebut dapat dijadikan sebagai sumber yang akurat untuk menjawab research question.

\section{Inclusion and Exclusion Criteria}

Pada tahapan ini peneliti menentukan beberapa kriteria untuk literatur yang dijadikan sebagai sumber acuan dan dinilai relevan dengan topik penelitian, diantaranya:

1. Literatur berbentuk jurnal dan conference dengan sifat full text.

2. Batas waktu publikasi minimal 5 tahun terakhir dengan rentang waktu dari tahun 20162020.

3. Literatur yang membahas tentang higher order thinking skills (HOTS) dan hasil belajar siswa.

4. Literatur yang disajikan dalam bahasa Indonesia.

D. Kualitas Penilaian (Quality Assesment)

Pada tahapan ini literatur yang telah ditentukan sebagai sumber acuan dan dinilai relevan dengan topik penelitian akan dilakukan identifikasi berdasarkan kriteria inklusi dan ekslusi yang telah dijabarkan sebelumnya. Pertanyaan ini dibuat untuk melihat kelayakan literatur yang telah terpilih. Pertanyaan yang ditentukan berdasarkan kriteria inklusi dan ekslusi, yaitu:

1. $\mathrm{QA}_{1}$ : Apakah literatur yang digunakan berbentuk jurnal dan conference yang disajikan full text?

2. $\mathrm{QA}_{2}$ : Apakah literatur yang digunakan sebagai sumber data diterbitkan dalam kurun waktu 5 tahun terakhir (2016-2020)?

3. $\mathrm{QA}_{3}$ : Apakah literatur tersebut membahas dan mengkaji tentang Higher Order Thinking Skills (HOTS) dan hasil belajar?

4. $\mathrm{QA}_{4}$ : Apakah literatur tersebut disajikan dalam Bahasa Indonesia?

Setelah melalui tahap identifikasi, literatur yang diperoleh akan diberikan keterangan berdasarkan pertanyaan diatas.

- Ya untuk kategori literatur yang sesuai dengan pertanyaan pada quality assessment diatas.

- Tidak untuk kategori literatur yang tidak sesuai dengan pertanyaan quality assessment diatas.

E. Proses Analisis Data

Tahapan ini mengacu pada proses analisis dan penjabaran hasil temuan yang diperoleh dari literatur-literatur yang terpilih. Hasil temuan tersebut disajikan dalam bentuk kesimpulan yang dijadikan sebagai dasar untuk memecahkan masalah dan menjawab research question yang telah ditentukan.

\section{HASIL DAN PEMBAHASAN}

\section{A. Hasil Proses Pencarian (Search Process) dan Inclusion and Exclusion Criteria}

Proses pencarian (search process) yang dilakukan pada tahap awal menghasilkan 1.687 literatur yang belum memasuki kriteria inklusi. Selanjutnya literatur yang diperoleh melalui beberapa tahap penyaringan (filter) untuk menentukan literatur yang dinilai relevan dengan topik penelitian. Diperoleh hasil akhir sebanyak 10 literatur yang relevan dengan topik penelitian yang diperoleh dari Google Scholar $(\mathrm{n}=5)$, Direct of Open Access Journals (DOAJ) $(n=3)$, dan Portal Garuda $(n=2)$. Pemilihan 10 literatur tersebut mengacu pada kriteria yang telah ditentukan, yaitu: (1) literatur berbentuk jurnal dan conference dengan sifat full text; (2) batas publikasi minimal 5 tahun terakhir (2016-2020); (3) literatur yang membahas higher order thinking skills (HOTS) dan hasil belajar siswa; dan (4) literatur yang disajikan dalam 
bahasa Indonesia. Hasil data yang diperoleh kemudian dikelompokkan berdasarkan jenis jurnal dan disajikan dalam bentuk Tabel 1 agar mudah dipahami oleh para pembaca.

Tabel 1. Klasifikasi Literatur Terpilih berdasarkan Jenis Jurnal

\begin{tabular}{|c|c|c|c|c|}
\hline No & Jenis Jurnal & Tahun & Sumber & Jumlah \\
\hline 1 & $\begin{array}{l}\text { Jurnal Pendidikan Matematika dan Sains, Vol. 1, } \\
\text { Hal. 51-57 }\end{array}$ & 2017 & DOAJ & 1 \\
\hline 2 & $\begin{array}{l}\text { Journal for Lesson and Learning Studies Vol. } 1 \\
\text { No. } 3\end{array}$ & 2018 & $\begin{array}{l}\text { Portal } \\
\text { Garuda }\end{array}$ & 1 \\
\hline 3 & $\begin{array}{l}\text { Jurnal Biology Science and Education Vol. 7, } \\
\text { No. } 1\end{array}$ & 2018 & $\begin{array}{l}\text { Google } \\
\text { Scholar }\end{array}$ & 1 \\
\hline 4 & $\begin{array}{l}\text { JPD: Jurnal Pendidikan Dasar DOI: } \\
\text { doi.org/10.21009/JPD.010.08 }\end{array}$ & 2018 & $\begin{array}{l}\text { Google } \\
\text { Scholar }\end{array}$ & 1 \\
\hline 5 & $\begin{array}{l}\text { Mosharafa: Jurnal Pendidikan Matematika Vol. } \\
8, \text { No. } 3\end{array}$ & 2019 & $\begin{array}{l}\text { Google } \\
\text { Scholar }\end{array}$ & 1 \\
\hline 6 & Jurnal Kumparan Fisika, Vol. 2, No. 2 & 2019 & DOAJ & 1 \\
\hline 7 & JPTM Vol. 09, No. 02, Hal. 37-43 & 2019 & $\begin{array}{l}\text { Portal } \\
\text { Garuda }\end{array}$ & 1 \\
\hline 8 & $\begin{array}{l}\text { Journal of Honai Math, Vol. 2, No. 2, pp. 117- } \\
188\end{array}$ & 2019 & DOAJ & 1 \\
\hline 9 & $\begin{array}{l}\text { Jurnal Inspirasi Manajemen Pendidikan, Vol. 08, } \\
\text { No. 02, Hal 100-107 }\end{array}$ & 2020 & $\begin{array}{l}\text { Google } \\
\text { Scholar }\end{array}$ & 1 \\
\hline 10 & $\begin{array}{l}\text { Jurnal THEOREMS (The Original Research of } \\
\text { Mathematics), Vol. 5, No. 1, Hal. 25-31 }\end{array}$ & 2020 & $\begin{array}{l}\text { Google } \\
\text { Scholar }\end{array}$ & 1 \\
\hline \multicolumn{4}{|c|}{ Total } & 10 \\
\hline
\end{tabular}

\section{B. Hasil Kualitas Penilaian (Quality Assesment)}

Berikut ini merupakan hasil dari quality assessment yang disajikan dalam Tabel 2.

Tabel 2. Kualitas Penilaian

\begin{tabular}{|c|l|c|c|c|c|c|}
\hline No & \multicolumn{1}{|c|}{ Penulis dan Tahun } & $\mathrm{QA}_{1}$ & $\mathrm{QA}_{2}$ & $\mathrm{QA}_{3}$ & $\mathrm{QA}_{4}$ & Hasil \\
\hline 1 & Karsono (2017) & $\mathrm{Y}$ & $\mathrm{Y}$ & $\mathrm{Y}$ & $\mathrm{Y}$ & Diterima \\
\hline 2 & $\begin{array}{l}\text { Bernandito P. Ngongo, Stefanus C. } \\
\text { Relmasira, Agustina Tyas Asri } \\
\text { Hardini (2018) }\end{array}$ & $\mathrm{Y}$ & $\mathrm{Y}$ & $\mathrm{Y}$ & $\mathrm{Y}$ & Diterima \\
\hline 3 & $\begin{array}{l}\text { Ahmad Yani, Muhsyanur, Shariah, } \\
\text { Haerunnisa, Sri Salmawati (2018) }\end{array}$ & $\mathrm{Y}$ & $\mathrm{Y}$ & $\mathrm{Y}$ & $\mathrm{Y}$ & Diterima \\
\hline 4 & $\begin{array}{l}\text { Wiratamasari Sarwinda, Septi Fitri } \\
\text { Meiliana (2018) }\end{array}$ & $\mathrm{Y}$ & $\mathrm{Y}$ & $\mathrm{Y}$ & $\mathrm{Y}$ & Diterima \\
\hline 5 & $\begin{array}{l}\text { Abdul Hakim Ma'ruf, Mohamad } \\
\text { Syafi'I, Arie Purwa Kusuma (2019) }\end{array}$ & $\mathrm{Y}$ & $\mathrm{Y}$ & $\mathrm{Y}$ & $\mathrm{Y}$ & Diterima \\
\hline 6 & $\begin{array}{l}\text { Safri Daryanti, Indra Sakti, Dedy } \\
\text { Hamdani (2019) }\end{array}$ & $\mathrm{Y}$ & $\mathrm{Y}$ & $\mathrm{Y}$ & $\mathrm{Y}$ & Diterima \\
\hline 7 & $\begin{array}{l}\text { Dinda Hasna Septianggraini, } \\
\text { Dewanto (2019) }\end{array}$ & $\mathrm{Y}$ & $\mathrm{Y}$ & $\mathrm{Y}$ & $\mathrm{Y}$ & Diterima \\
\hline 8 & Nurmala R, Alfian Mucti (2019) & $\mathrm{Y}$ & $\mathrm{Y}$ & $\mathrm{Y}$ & $\mathrm{Y}$ & Diterima \\
\hline 9 & $\begin{array}{l}\text { Riqi Cahyawati, Muhammad } \\
\text { Sholeh (2020) }\end{array}$ & $\mathrm{Y}$ & $\mathrm{Y}$ & $\mathrm{Y}$ & $\mathrm{Y}$ & Diterima \\
\hline 10 & Iwan Kurniawan (2020) & $\mathrm{Y}$ & $\mathrm{Y}$ & $\mathrm{Y}$ & $\mathrm{Y}$ & Diterima \\
\hline
\end{tabular}


Keterangan:

- Ya (Y) untuk kategori literatur yang digunakan dan relevan dengan penelitian yang dilakukan. Data tersebut dipilih sebagai sumber utama karena memiliki topik penelitian yang saling berkaitan, membahas dan mengkaji mengenai HOTS dan hasil belajar serta dianggap memiliki informasi yang cukup luas.

- Tidak (T) untuk kategori literatur yang tidak digunakan dalam proses penelitian sebab tidak relevan dengan topik penelitian yang sedang diteliti dan dinilai kurang memadai mengenai informasi yang disajikan.

\section{Hasil Analisis Data (Data Analysis)}

Tahapan ini akan menjabarkan sekaligus menjawab research question yang telah ditentukan sebelumnya.

1. $\mathrm{RQ}_{1}$ : Bagaimana penerapan Higher Order Thinking Skills (HOTS) di tingkat SD/MI terhadap hasil belajar siswa?

Berdasarkan hasil analisis data pada 10 literatur yang telah memenuhi kriteria inklusi dan melalui tahap quality assesment dapat ditarik kesimpulan bahwa 9 dari 10 hasil literatur atau sebesar 90\% menunjukkan jika penerapan HOTS dalam proses pembelajaran efektif dan berpengaruh positif terhadap hasil belajar siswa secara signifikan dibandingkan dengan pembelajaran konvensional. Hal ini ditunjukkan pada Tabel 3

Tabel 3. Persentase Hasil Literatur

\begin{tabular}{|c|c|c|c|c|}
\hline No & Penulis/Tahun & Judul & Hasil & Persentase \\
\hline 1 & $\begin{array}{l}\text { Karsono } \\
(2017)\end{array}$ & $\begin{array}{l}\text { Pengaruh penggunaan LKS berbasis } \\
\text { HOTS terhadap motivasi dan hasil } \\
\text { belajar IPA siswa SMP }\end{array}$ & $\begin{array}{l}\text { Tidak } \\
\text { Efektif }\end{array}$ & $0 \%$ \\
\hline 2 & $\begin{array}{l}\text { Bernandito P. } \\
\text { Ngongo et al. } \\
\text { (2018) }\end{array}$ & $\begin{array}{l}\text { Penerapan HOTS dalam model } \\
\text { pembelajaran Small Group Discussion } \\
\text { untuk meningkatkan hasil belajar } \\
\text { PPKN }\end{array}$ & Efektif & $10 \%$ \\
\hline 3 & $\begin{array}{l}\text { Ahmad Yani } \\
\text { et al. (2018) }\end{array}$ & $\begin{array}{l}\text { Efektivitas pendekatan saintifik } \\
\text { dengan media booklet HOT terhadap } \\
\text { hasil belajar biologi siswa SMA di } \\
\text { kab. Wajo }\end{array}$ & Efektif & $10 \%$ \\
\hline 4 & $\begin{array}{l}\text { Wiratamasari } \\
\text { Sarwinda } \text { et al. } \\
\text { (2018) }\end{array}$ & $\begin{array}{l}\text { Pengaruh penggunaan worksheet IPA } \\
\text { berorientasi HOTS terhadap hasil } \\
\text { belajar kognitif siswa SD } \\
\text { Muhammadiyah } 4 \text { dan } 5 \text { Jakarta }\end{array}$ & Efektif & $10 \%$ \\
\hline 5 & $\begin{array}{l}\text { Abdul Hakim } \\
\text { Ma'ruf } \text { et al. } \\
\text { (2018) }\end{array}$ & $\begin{array}{l}\text { Pengaruh model pembelajaran Mind } \\
\text { Mapping berbasis HOTS terhadap } \\
\text { motivasi dan hasil belajar siswa }\end{array}$ & Efektif & $10 \%$ \\
\hline 6 & $\begin{array}{l}\text { Safri Daryanti } \\
\text { et al. (2019) }\end{array}$ & $\begin{array}{l}\text { Pengaruh pembelajaran model } \\
\text { Problem Solving berorientasi HOTS } \\
\text { terhadap hasil belajar fisika dan } \\
\text { kemampuan pemecahan masalah }\end{array}$ & Efektif & $10 \%$ \\
\hline 7 & $\begin{array}{l}\text { Dinda Hasna } \\
\text { et al. (2019) }\end{array}$ & $\begin{array}{l}\text { Penerapan model pembelajaran } \\
\text { Problem Based Learning } \\
\text { menggunakan soal HOTS untuk } \\
\text { meningkatkan hasil belajar siswa kelas } \\
\text { X TPM } 2 \text { pada mata pelajaran DPTM } \\
\text { di SMK Dharma Bahari Surabaya }\end{array}$ & Efektif & $10 \%$ \\
\hline
\end{tabular}




\begin{tabular}{|c|l|l|c|c|}
\hline 8 & $\begin{array}{l}\text { Nurmala R } \text { et } \\
\text { al. }(2019)\end{array}$ & $\begin{array}{l}\text { Efektivitas penggunaan LKM berbasis } \\
\text { HOTS terhadap hasil belajar } \\
\text { mahasiswa pendidikan matematika" }\end{array}$ & Efektif & $10 \%$ \\
\hline 9 & $\begin{array}{l}\text { Riqi } \\
\text { Cahyawati } \text { et } \\
\text { al. }(2020)\end{array}$ & $\begin{array}{l}\text { Pengaruh HOTS dan manajemen kelas } \\
\text { terhadap hasil belajar siswa di SMPN } \\
\text { 28 Surabaya }\end{array}$ & Efektif & $10 \%$ \\
\hline 10 & $\begin{array}{l}\text { Iwan } \\
\text { Kurniawan } \\
(2020)\end{array}$ & $\begin{array}{l}\text { Penggunaan model pembelajaran } \\
\text { Discovery Learning berorientasi } \\
\text { HOTS sebagai upaya meningkatkan } \\
\text { hasil belajar siswa }\end{array}$ & Efektif & $10 \%$ \\
\hline \multicolumn{3}{|c|}{ Total } & $90 \%$ \\
\hline
\end{tabular}

Mengacu pada hasil analisis terhadap 10 literatur tersebut maka dapat dikatakan penerapan HOTS dalam proses pembelajaran yang dilaksanakan pada tingkat SD/MI efektif terhadap hasil belajar siswa yang ditandai dengan perubahan pada aspek kognitif siswa yang awalnya cenderung berpikir dengan level rendah (LOTS) pada pembelajaran konvensional menuju kemampuan berpikir tingkat tinggi (HOTS) yang meliputi kemampuan berpikir kritis, kreatif, dan evaluatif. Ketiga aspek tersebut membekali siswa dengan konsep pemikiran yang matang untuk menghadapi sekaligus menyelesaikan permasalahan dalam situasi atau kondisi tertentu. Sejatinya penerapan HOTS berkaitan erat dengan konsep penyajian suatu topik atau masalah tertentu yang semata-mata bertujuan agar peserta didik mampu menciptakan secara mandiri cara belajar yang aktif sekaligus menggali konsep yang sedang dipelajari melalui transformasi pengetahuan yang diperolehnya ke dalam bentuk rancangan strategi dan solusi yang tepat untuk menyelesaikan masalah pembelajaran yang berkaitan langsung dengan kehidupan sehari-hari. Seiring dengan hal tersebut, perbedaan yang signifikan terlihat pada aktivitas belajar siswa yang mengalami peningkatan seperti siswa jauh lebih antusias, aktif, dan percaya diri ketika menyampaikan argumen yang berkaitan dengan konsep pembelajaran yang sedang dipelajari sehingga memicu pada peningkatan motivasi belajar siswa secara signifikan. Dengan demikian siswa akan terbiasa untuk mendominasi perannya selama mengikuti pembelajaran tersebut, hal ini menunjukkan jika HOTS merubah konsep pembelajaran yang awalnya berpusat pada guru (teacher centered) menjadi berpusat pada siswa (student centered) sekaligus menegaskan jika peran siswa tidak hanya terbatas pada kegiatan menulis, memperhatikan, mengingat, dan mendengarkan materi atau informasi yang sedang atau telah sampaikan. Konsep pembelajaran HOTS yang berpusat pada siswa (student centered) dinilai berpengaruh besar terhadap interaksi dan komunikasi yang dibangun oleh peserta didik secara dua arah baik dengan antar siswa maupun dengan guru sehingga memaksimalkan proses pembelajaran yang berlangsung agar mengarah pada kualitas pembelajaran yang efektif, efisien, progresif, dan mencapai kriteria atau tujuan yang telah ditentukan.

Muatan pembelajaran HOTS tidak terlepas dari penyajian topik atau masalah tertentu yang secara tidak langsung melibatkan interaksi dan komunikasi antar siswa melalui kegiatan diskusi yang dilaksanakan, konsep pembelajaran seperti ini semata-mata membangun pola hubungan humanis antar siswa sekaligus memberikan kesempatan pada setiap siswa untuk mampu menyampaikan argumen atas permasalahan yang disajikan. Dengan melihat suatu permasalahan dari berbagai sudut pandang tertentu memungkinkan siswa untuk dapat memahami secara utuh masalah yang disajikan sekaligus menentukan solusi yang efektif dalam memecahkan masalah melalui musyawarah dan kesepakatan yang dilakukan secara bersama-sama. Dalam hal ini siswa akan terbiasa menerima dan menyampaikan kritik dengan baik yang semata-mata ditujukan untuk mengembangkan kemampuan siswa dalam mengidentifikasi dan menganalisis suatu permasalahan disituasi atau kondisi tertentu. Sejatinya penerapan HOTS mengacu pada proses keseimbangan antara peran guru dan siswa Al-Adzka: Vol. 10, No. 2, Desember 2020 
yang saling melengkapi, dimana guru berkontribusi melalui perannya sebagai fasilitator, motivator, dan evaluator sedangkan siswa berupaya untuk mendalami perannya sebagai partisipan yang aktif secara utuh. Proses pembelajaran harus memaksimalkan kinerja otak dalam proses berpikir, sehingga kemampuan berpikir siswa dapat terus berkembang secara optimal dan mencapai pada keterampilan berpikir tingkat tinggi. HOTS bukan hanya berpengaruh positif pada aspek kognitif dan aktivitas belajar siswa saja, namun juga memberikan dampak terhadap kemampuan sosial siswa dimana siswa memiliki keterampilan dalam membangun pola komunikasi dan interaksi serta mampu menempatkan diri dalam berbagai lingkungan. Upaya yang dilakukan untuk memaksimalkan proses perkembangan pada aspek kognitif siswa yang mengarah pada kemampuan berpikir tingkat tinggi adalah dengan menerapkan HOTS dengan tepat dan benar. Penerapan HOTS utamanya harus mengacu dan memperhatikan pada kebutuhan siswa, situasi dan kondisi kelas yang diciptakan, kemampuan siswa yang beragam serta gaya belajar yang biasa digunakan. Dengan memperhatikan aspek-aspek tersebut tentunya akan memaksimalkan proses pembelajaran yang berlangsung sehingga mengarah pada kualitas pembelajaran yang efektif sekaligus menciptakan sumber daya manusia (SDM) yang berkompeten dan berkontribusi positif dilingkungan sekitarnya sehingga mencapai pada kriteria pembelajaran yang optimal.

2. $\mathrm{RQ}_{2}$ : Apa sajakah faktor pendukung dan penghambat penerapan HOTS di tingkat $\mathrm{SD} / \mathrm{MI}$ ?

Penerapan HOTS akan mencapai pada kriteria atau tujuan pembelajaran yang telah ditentukan apabila dilaksanakan dengan baik dan benar. Untuk mencapai keberhasilan tersebut guru memiliki peran yang cukup besar terhadap pemenuhan segala kebutuhan yang diperlukan oleh siswa guna menunjang proses pembelajaran yang dilaksanakan agar berjalan secara optimal dan menghasilkan mutu pembelajaran yang berkualitas. Disisi lain guru dituntut untuk mampu memahami setiap karakter siswa secara utuh, mengetahui kendala maupun kesulitan yang dihadapi oleh siswa selama atau setelah mengikuti proses pembelajaran yang menerapkan HOTS hingga mengetahui jenis dan gaya pembelajaran yang tepat untuk masing-masing siswa agar dapat dijadikan sebagai landasan untuk memberikan pelayanan dan penanganan yang tepat sebagai upaya yang dilakukan untuk mencapai pada kriteria yang diharapkan sekaligus meminimalisir hal-hal yang dapat menghambat pelaksanaan proses pembelajaran tersebut. Ada beberapa komponen penting yang dapat diperhatikan untuk menunjang kelangsungan penerapan HOTS dalam proses kegiatan belajar mengajar (KBM) yang dilaksanakan. Komponen tersebut diklasifikasikan menjadi dua bagian, yaitu faktor pendukung dan faktor penghambat. Faktor pendukung dikatakan sebagai segenap komponen penting yang dinilai mampu menunjang keberhasilan proses penerapan HOTS dalam kegiatan belajar mengajar (KBM). Faktor pendukung tersebut dapat dijabarkan sebagai berikut:

a. Kompetensi guru

Menurut (Imam, 2012:240) (dalam Mulyana, 2003:1) dikatakan jika kompetensi guru dalam melaksanakan proses pembelajaran sesuai dengan prosedur yang berlaku merupakan salah satu indikator yang berpengaruh cukup besar terhadap perkembangan potensi akademik yang dimiliki siswa. Kompetensi guru adalah serangkaian penguasaan terhadap keterampilan, kemampuan, sikap, dan penguatan yang harus dimiliki bahkan dikuasai oleh guru guna menunjang proses pembelajaran yang dilaksanakan serta mencapai pada kriteria tenaga pendidik yang profesional, unggul, berkualitas serta turut serta meningkatkan kinerja profesinya secara progresif (Novauli, 2015: 46). Sebagaimana yang tertuang dalam UndangUndang Nomor 14 Tahun 2005 Pasal 10 Ayat 1 tentang Guru dan Dosen "Kompetensi guru meliputi kompetensi pedagogik, kompetensi kepribadian, kompetensi sosial, dan kompetensi 
profesional yang diperoleh melalui pendidikan profesi”. Keempat kompetensi tersebut dapat dijabarkan sebagai berikut:

1) Kompetensi pedagogik diartikan sebagai suatu keterampilan yang berkenaan dengan pelaksanaan dan pengelolaan proses pembelajaran yang berlangsung agar berjalan secara optimal dan efektif sehingga mencapai pada tujuan yang telah digariskan (Fathurrohman, P, 2017:44). Dalam hal ini guru harus memiliki kemampuan untuk melaksanakan konsep pembelajaran secara tepat dan benar dengan memperhatikan pada aspek kebutuhan, gaya belajar, situasi serta kondisi kelas, dan kesulitan yang dihadapi oleh siswa. Dengan demikian ketika guru mampu mengaplikasikan konsep pembelajaan HOTS dengan baik, maka akan menghasilkan kualitas dan mutu pembelajaran yang efektif sesuai dengan tujuan yang ingin dicapai yakni membekali siswa dengan kemampuan berpikir tingkat tinggi dan turut serta mengembangkan kemampuan berpikir sistematis, kritis, dan kreatif sebagai dasar untuk menghadapi tantangan di abad 21 seperti saat ini.

2) Kompetensi kepribadian yaitu berkenaan dengan kemampuan guru untuk bersikap ataupun memiliki perilaku yang baik agar dapat menjadi panutan dan contoh bagi peserta didik. Dalam kesehariannya peserta didik akan melihat dan meniru apa yang dilakukan oleh orang yang dikaguminya, sebab itu guru harus mampu memberikan contoh-contoh positif dengan memiliki kepribadian yang baik seperti berakhlak mulia, sopan dan santun, lemah lembut, cinta dan kasih terhadap sesama, jujur, adil, bertanggung jawab dan lain-lain. Penerapan HOTS dinilai sulit dan cukup rumit bagi sebagian siswa, namun pemanfaatan kompetensi kepribadian yang dimiliki guru secara tepat dapat merubah persepsi yang dibangun oleh siswa yakni dengan menunjukkan sikap sabar, ulet, bekerja keras, dan tidak mudah menyerah dalam mencapai tujuan yang ditentukan. Walaupun siswa terbiasa dengan pembelajaran konvensional, namun guru harus berkeyakinan bahwa usaha yang dilakukannya dalam memaksimalkan penerapan HOTS akan menghasilkan kualitas pembelajaran yang efektif melalui sikap ataupun contoh yang ditunjukannya tersebut. Dengan demikian siswa dapat meniru sikap yang ditunjukkan oleh gurunya sebagai sosok yang dikagumi dan dijadikannya sebagai panutan.

3) Kompetensi sosial adalah kemampuan guru dalam membangun interaksi dan komunikasi yang baik seperti dengan para guru, kepala sekolah, orang tua murid hingga lingkungan masyarakat. Dalam hal ini guru dituntut untuk menciptakan interaksi dan komunikasi yang berjalan secara harmonis seperti dengan kepala sekolah sebagai bentuk usaha yang dilakukan untuk mendapatkan dukungan dan komitmen dalam meningkatkan kualitas pembelajaran melalui penerapan HOTS. Disisi lain guru juga dapat melakukan diskusi secara berkala dengan para guru lainnya agar dapat memaksimalkan pemahaman konsep dan aplikasi HOTS secara optimal. Sementara dalam lingkungan masyarakat guru dapat berperan untuk memberikan kontribusi positif dalam bentuk edukasi yang diberikan terkait konsep dan aplikasi HOTS yang dapat diterapkan pula dilingkungan keluarga. Hal ini bertujuan untuk menyeimbangkan pengetahuan yang diperoleh disekolah dengan penyempurnaan yang dilakukan dirumah melalui peran dan dukungan keluarga secara aktif.

4) Kompetensi profesional merupakan kemampuan yang merujuk pada peran guru dalam menjalankan tugasnya dan menguasai bidang ilmu tertentu sebagai tenaga pendidik yang berkompeten dan berkualitas sehingga dapat membimbing siswa agar menguasai pengetahuan atau keterampilan yang diharapkan secara optimal. Guru juga harus menyampaikan pengetahuan dengan konsep yang sederhana dan mudah dipahami oleh siswa, artinya ketika guru memaparkan konsep pembelajaran HOTS yang cukup rumit dan padat maka guru harus kreatif dan terampil dalam menyajikan materi tersebut dengan gaya yang unik namun tetap memperhatikan pada aspek tujuan yang ingin dicapai. Kreatifitas guru bukan hanya sebatas memodifikasi materi pembelajaran yang disampaikan dengan konsep yang sederhana, namun juga dapat dilakukan dengan menggabungkan konsep pembelajaran dengan keterampilan 
yang dimiliki oleh siswa sehingga memudahkan siswa untuk memahami pembelajaran yang diperoleh sekaligus memberikan pengalaman serta makna tersendiri bagi siswa setelah mengikuti proses pembelajaran tersebut. Dengan demikian dapat dikatakan jika guru harus memiliki kemampuan dalam menguasai materi pembelajaran secara luas dan utuh sehingga merujuk pada upaya mengarahkan siswa untuk memenuhi standar kompetensi dan mencapai kriteria yang ditetapkan.

b. Sarana prasarana

Jika merujuk pada definisinya sarana dikatakan sebagai perlengkapan yang tersedia dan secara langsung digunakan untuk menunjang proses pembelajaran agar berjalan optimal yang mencakup ketersediaan meja, kursi, bahan ajar dan media pembelajaran (Fatmawati, 2019:116) (dalam Fuad, 2016:1). Sementara prasarana adalah segenap fasilitas yang secara tidak langsung menunjang proses pelaksanaan pembelajaran seperti halaman, taman, lapangan, bangunan sekolah, ruang laboratorium dan lain-lain. Dengan demikian sarana prasarana merupakan sebuah kelengkapan pada fasilitas yang digunakan dalam proses pembelajaran baik yang bergerak maupun tidak bergerak sebagai wujud dalam mencapai pada tujuan pembelajaran yang diharapkan dan menghasilkan kualitas pembelajaran yang optimal (Fathurrohman, 2019:178). Penerapan HOTS dalam kegiatan belajar mengajar (KBM) akan mencapai hasil yang diinginkan apabila didukung dan terpenuhinya sarana yang menunjang kelangsungan pembelajaran tersebut salah satunya ketersediaan ruangan kelas yang luas, nyaman, bersih, dan cukup akan pencahayaan sehingga dapat menciptakan suasana pembelajaran yang kondusif, aktif, dan menyenangkan serta memaksimalkan proses penerapan materi oleh siswa secara optimal. Sementara prasarana yang tersedia dapat dijadikan sebagai alternatif dalam pemenuhan pengetahuan siswa.

Pembelajaran yang umumnya dilaksanakan didalam kelas dapat diselenggarakan diluar lingkungan kelas seperti taman, lapangan, halaman sekolah maupun laboratorium yang dapat digunakan sebagai media pembelajaran dan sekaligus memberikan kesan tersendiri bagi siswa setelah mengikuti pembelajaran tersebut. Menurut (Firmansyah, 2018:180) pengelolaan sarana prasarana yang baik dan dimanfaatkan secara optimal berpengaruh besar terhadap pencapaian tujuan pembelajaran yang mengarah pada peningkatan hasil dan prestasi siswa dibidang akademik.

c. Manajemen kelas

Manajemen kelas adalah sebuah keterampilan yang harus dikuasai oleh guru dalam bentuk mengelola dan mengendalikan kebutuhan siswa, situasi dan kondisi kelas serta hambatan yang dilalui siswa selama atau setelah mengikuti pembelajaran (Pamela, 2019:24). Dalam hal ini pengelolaan kelas yang dimaksud adalah menjaga konsistensi suasana dan kondisi kelas agar berjalan secara kondusif dengan melibatkan siswa secara aktif sebagai partisipan dan turut serta mengaplikasikan sarana prasarana yang tersedia sebagai wujud pemanfaatan penunjang pembelajaran secara optimal. Dalam pelaksanaannya guru dituntut untuk mampu membaca situasi kelas agar dapat memenuhi kebutuhan dan menangani kesulitan yang dihadapi siswa serta melihat peluang yang tersedia untuk memaksimalkan proses pembelajaran yang sedang berlangsung. Seorang guru bukan hanya sekedar menyampaikan materi pembelajaran saja, namun juga dapat terlibat dalam upaya memodifikasi kelas secara unik dan kreatif sebagai contoh melakukan penataan ulang pada kelas secara berkala. Dalam penerapan HOTS yang bermuatan pemecahan masalah dan mengharuskan siswa untuk melakukan diskusi guru dapat membentuk pola terhadap kursi dan meja yang digunakan dengan tujuan agar terciptanya interaksi dan komunikasi yang baik antar siswa khususnya dalam melakukan musyawarah sekaligus menentukan solusi yang tepat atas masalah yang disajikan. 


\section{d. Perencanaan pembelajaran}

Perencanaan pembelajaran diartikan sebagai sebuah langkah dan upaya yang dilakukan dalam proses pembelajaran yang berlangsung sehingga mengarah pada proses perkembangan kualitas siswa yang produktif, pembelajaran yang optimal, dan mencapai pada tujuan yang diharapkan (Uno, 2016: 1-2). Perencanaan pembelajaran mencakup pada pembuatan RPP, pemilihan sumber dan bahan ajar serta penentuan metode dan strategi yang tepat yang dipersiapkan secara matang guna menunjang keberhasilan proses pembelajaran yang akan dilaksanakan. Dalam menerapkan HOTS guru dituntut untuk mampu merancang RPP dengan baik dan benar yang mengacu pada silabus serta kurikulum yang berlaku dengan memperhatikan pada indikator yang digambarkan melalui KD yang ingin dicapai. Sedangkan pemilihan metode dan strategi pembelajaran harus memperhatikan pada kebutuhan siswa serta situasi dan kondisi kelas agar penggunaan metode dan strategi dapat memaksimalkan pembelajaan yang berlangsung. Hal ini dapat dijadikan tolak ukur untuk menentukan metode dan strategi yang tepat agar dapat dipadu-padankan dengan pembelajaran HOTS sehingga keduanya dapat saling melengkapi dan mencapai pada tujuan yang diharapkan.

Faktor penghambat merupakan komponen dalam bentuk suatu kendala maupun kesulitan yang dihadapi ketika menerapkan HOTS yang mengakibatkan pada ketidakmampuan untuk mencapai tujuan yang ditentukan. Faktor penghambat meliputi kualifikasi pendidikan guru yang kurang memadai dan tingkat pemahaman guru yang relatif rendah. Faktor penghambat tersebut dapat dijabarkan sebagai berikut:

a. Kualifikasi pendidikan guru yang kurang memadai

Sebagaimana yang tertuang dalam Lampiran Peraturan Menteri Pendidikan Nasional Nomor 16 Tahun 2007 Tanggal 4 Mei 2007 tentang Standar Kualifikasi Akademik dan Kompetensi Guru "Guru pada SD/MI atau bentuk lain yang sederajat harus memiliki kualifikasi akademik pendidikan minimal diploma empat (D-IV) atau sarjana (S1) dalam bidang pendidikan SD/MI (D-IV/S1) PGSD/PGMI atau psikologi yang diperoleh dari program studi yang terakreditasi. Artinya penerapan konsep pembelajaran yang dilaksanakan oleh tenaga pendidik yang berlatar belakang pendidikan dan ahli dibidangnya akan memaksimalkan proses pembelajaran yang berlangsung sekaligus turut serta mengembangkan kualitas pembelajaran yang progresif dan menghasilkan sumber daya manusia (SDM) yang berkompeten khususnya ditingkat dasar. Sementara melihat realita yang terjadi tenaga pendidik yang tersedia umumnya telah memenuhi kualifikasi pendidikan minimal diploma empat (D-IV) atau sarjana (S1) namun tidak berkonsentrasi pada bidang SD/MI. Banyak diantara tenaga pendidik yang berprofesi sebagai guru SD/MI memiliki latar belakang yang beragam seperti berkonsentrasi dibidang non PGSD/PGMI. Guru memiliki peranan yang cukup besar sebagai ujung tombak dalam keberhasilan suatu pembelajaran yang dilaksanakan sehingga mencapai pada tujuan yang diharapkan (Susanti, 2020:53).

Dengan demikian guru yang bukan berlatar belakang pendidikan bidang SD/MI serta tidak menguasai kompetensi guru dan memiliki pengalaman dalam melaksanakan pembelajaran ditingkat dasar akan mengalami kendala dalam menerapkan konsep pembelajaran khususnya penerapan HOTS yang dinilai cukup rumit. Hal ini disebabkan oleh ketidakmampuan untuk memahami secara teoritis dan mengaplikasikannya dalam kegiatan belajar mengajar (KBM) yang berlangsung. Situasi ini akan memicu pada rendahnya upaya dan kiat-kiat yang dilakukan pihak sekolah dalam meningkatkan kualitas pendidikan dan mutu pembelajaran melalui penerapan HOTS sebagai langkah untuk membekali dan mengembangkan kemampuan berpikir siswa agar terbiasa berpikir dengan level yang lebih tinggi meliputi kemampuan berpikir kritis, kreatif, dan evaluatif sebagai dasar untuk menghadapi tantangan, problematika, dan perubahan zaman di era globalisasi seperti saat ini. 
b. Tingkat pemahaman guru yang relatif rendah terhadap HOTS

Salah satu faktor pemicu rendahnya pemahaman guru terhadap penerapan HOTS ialah minimnya pelatihan dan pendampingan yang diberikan oleh pihak atau instansi terkait seperti Dinas Pendidikan setempat (Budiarta, 2018:110). Pelatihan maupun pendampingan yang umumnya dilaksanakan masih bersifat secara teoritis dan terpaku pada proses penyampaian materi yang cenderung padat oleh pembicara ataupun narasumber. Dalam hal ini guru yang notabenenya merupakan pendengar menjadi pasif sebab terbatas pada kegiatan mendengarkan, menulis materi-materi yang disampaikan oleh narasumber, dan mengingat hal-hal yang dianggap penting tanpa dilibatkan secara aktif dan utuh selama mengikuti pelatihan tersebut. Dengan demikian kemampuan guru akan terbatas pada pemahaman mengenai konsep HOTS, namun cenderung kesulitan dalam mengaplikasikan teori yang diperolehnya dalam melaksanakan proses pembelajaran yang menerapkan HOTS. Ketidakseimbangan antara teori yang disajikan dengan proses pengaplikasiannya hanya akan membangun persepsi guru mengenai penerapan HOTS secara negatif dimana dalam pelaksanaannya guru beranggapan bahwa HOTS cenderung rumit, berbelit-belit, menimbulkan kesulitan pada diri siswa hingga membutuhkan waktu yang cukup lama.

Sejatinya penyampaian materi yang dilakukan harus melihat pada aspek keseimbangan dan penyempurnaan. Pembicara sebagai narasumber harus menciptakan interaksi dan komunikasi dua arah dengan melibatkan pendengar secara aktif sehingga dapat menekan tingginya kemampuan yang terbatas pada mengingat dan menghafal yang selama ini menjadi kendala dalam penguasaan materi yang disajikan dengan mengarah pada kemampuan memahami konsep yang disajikan agar dimengerti secara utuh serta memenuhi kualifikasi yang diharapkan. Penyempurnaan yang dilakukan semata-mata bertujuan untuk memaksimalkan pemahaman mengenai konsep HOTS yang dapat diupayakan melalui pelatihan yang berorientasi pada kegiatan pengaplikasian HOTS dengan benar khususnya ditingkat dasar. Langkah ini dapat menunjang pemahaman yang telah dikuasai oleh guru sehingga dapat tersalurkan dalam bentuk pelaksanaan proses pembelajaran yang dilakukan sehari-hari dengan menerapkan HOTS secara tepat. Koordinasi serta komitmen dari Dinas Pendidikan serta Kepala Sekolah harus dibangun secara humanis sebagai bentuk dukungan dalam melakukan pelatihan dan pendampingan secara berkala terlebih dalam mengupayakan penerapan HOTS sejak dini mulai ditingkat SD/MI sekaligus membekali tenaga pendidik untuk mengembangkan kompetensi yang dimilikinya agar dapat memenuhi kualifikasi guru yang profesional dan berkompeten dibidang SD/MI.

\section{PENUTUP}

Penerapan HOTS dalam proses pembelajaran di tingkat SD/MI dinilai efektif dan memberikan optimalisasi secara positif terhadap hasil belajar siswa yang ditandai dengan peningkatan pada aspek kognitif siswa yang mengarah pada kemampuan berpikir tingkat tinggi yang meliputi kemampuan berpikir kritis, kreatif, dan evaluatif. Hal ini berbanding lurus pada aktivitas belajar siswa yang cukup signifikan dimana proses pembelajaran yang berlangsung berpusat pada siswa (student centered) dengan melibatkan siswa secara aktif sebagai partisipan sekaligus memberikan impact positif terhadap interaksi serta komunikasi yang tercipta secara dua arah yakni siswa dengan siswa dan siswa dengan guru sehingga mengarah pada pembelajaran yang efektif, efisien, progresif, dan mengacu pada ketercapaian kriteria atau tujuan yang telah ditentukan.

Keberhasilan HOTS dalam proses pembelajaran tidak terlepas dari faktor pendukung yang meliputi kompetensi guru, sarana prasarana, manajemen kelas serta perencanaan pembelajaran, sedangkan faktor penghambat meliputi kualifikasi pendidikan guru yang kurang memadai dan tingkat pemahaman guru yang relatif rendah terhadap HOTS. Untuk 
memaksimalkan proses pembelajaran yang menerapkan konsep HOTS upayanya guru harus mengacu dan berpedoman pada komponen-komponen tersebut agar dapat mencapai pada kriteria dan kualitas pembelajaran yang diharapkan serta dapat menekan angka ketidaktercapaian tujuan pembelajaran yang sedang atau telah dilaksanakan.

\section{DAFTAR PUSTAKA}

Arifin, Z. (2017). Mengembangkan Instrumen Pengukur Critical Thinking Skills Siswa pada Pembelajaran Matematika Abad 21. Jurnal THEOREMS (The Original Research of Mathematics), 1, (2), 95.

Budiarta. (2018). Potret Implementasi Pembelajaran Berbasis High Order Thinking Skills (HOTS) di Sekolah Dasar Kota Medan. Jurnal Pembangunan Perkotaan. 6, (2), 110.

Fathurrohman, P. (2017). Strategi Belajar Mengajar. Bandung: PT Refika Aditama.

Fatmawati, L. (2017). Perbedaan Hasil Belajar Siswa Melalui Pendekatan Konvensional Dengan Pendekatan Saintifik Pada Kompetensi Dasar Fungsi Manajemen Siswa Kelas X di SMAN 4 Jember Tahun Ajaran 2016/2017. Jurnal Pendidikan Ekonomi. 11, (2), 135.

Fatmawati, N. (2018). Pemanfaatan dan Pemeliharaan Sarana dan Prasarana Pendidikan. PEMBELAJAR: Jurnal Ilmu Pendidikan, Keguruan, dan Pembelajaran. 3, (2), 116.

Firmansyah, T. (2018). Efektivitas Pemanfaatan Sarana dan Prasarana dalam Meningkatkan Mutu Layanan. JMSP: Jurnal Manajemen dan Supervisi Pendidikan, 2 (3), 180.

Karsono. (2017). Pengaruh Penggunaan LKM Berbasis HOTS Terhadap Motivasi dan Hasil Belajar IPA Siswa SMP. Jurnal Pendidikan Matematika dan Sains, 1, 51.

Muhyani. (2019) Metodologi Penelitian. Bogor: UIKA Press.

Novauli, F. (2015). Kompetensi Guru dalam Peningkatan Prestasi Belajar Pada SMP Negeri Dalam Kota Banda Aceh. Jurnal Administrasi Pendidikan, 3 (1), 46.

Pamela, I. (2019). Keterampilan Guru dalam Mengelola Kelas. Edustream: Jurnal Pendidikan Dasar, 3 (2), 24.

Putri. (2013). Faktor-faktor Penyebab Rendahnya Prestasi Belajar Siswa (Studi Deskriptif Terhadap Siswa SMPN 12 Padang). Konselor: Jurnal Ilmiah Konseling, 2 (1), 225.

Rapih, S. (2018). Perspektif Guru Terhadap Higher Order Thinking Skills (HOTS): Pemahaman, Penerapan, dan Hambatan. Premiere Educandum: Jurnal Pendidikan Dasar dan Pembelajaran, 8 (1), 77.

Suraji, Imam. (2012). Urgensi Kompetensi Guru. Jurnal Forum Tarbiyah, 10. (2), 240.

Susanti, Endang. (2020). Strategi Guru dalam Pembelajaran Berhitung Pembagian di Sekolah Dasar. Jurnal Al-Adzka, 1, (1), 53.

Triandini, E. (2019). Metode Systematic Literature Review Untuk Identifikasi Platform dan Metode Pengembangan Sistem Informasi di Indonesia. Indonesia Journal of Information Systems (JIS), 1 (2), 64.

Uno, Hamzah. (2016). Perencanaan Pembelajaran. Jakarta: PT Bumi Aksara.

Wahyudin, D. (2007). Pengantar Pendidikan. Jakarta: Universitas Terbuka.

Yani, A. (2016). Efektivitas Pendekatan Saintifik dengan Media Booklet HOTS Terhadap Hasil Belajar Biologi Siswa di Kabupaten Wajo. Jurnal Biology Science and Education, 7 (1), 2.

Zulyadaini. (2016). Perbandingan Hasil Belajar Matematika Model Pembelajaran Kooperatif Tipe Coop-Coop Dengan Konvensional. Jurnal Ilmiah, 16 (1), 154. 